\title{
Performance metrics and required returns for UK real estate development schemes
}

Article

Accepted Version

Crosby, N., Devaney, S. and Wyatt, P. (2020) Performance metrics and required returns for UK real estate development schemes. Journal of Property Research, 37 (2). pp. 171-193. ISSN 1466-4453 doi:

https://doi.org/10.1080/09599916.2020.1720269 Available at https://centaur.reading.ac.uk/88612/

It is advisable to refer to the publisher's version if you intend to cite from the work. See Guidance on citing.

To link to this article DOI: http://dx.doi.org/10.1080/09599916.2020.1720269

Publisher: Routledge

All outputs in CentAUR are protected by Intellectual Property Rights law, including copyright law. Copyright and IPR is retained by the creators or other copyright holders. Terms and conditions for use of this material are defined in the End User Agreement.

\section{www.reading.ac.uk/centaur}

\section{CentAUR}

Central Archive at the University of Reading 
Reading's research outputs online 


\title{
Performance metrics and required returns for UK real estate development schemes
}

\author{
Neil Crosby* \\ Steven Devaney \\ Pete Wyatt

\section{Department of Real Estate \& Planning} \\ University of Reading
}

*Corresponding author email: f.n.crosby@rdg.ac.uk

\begin{abstract}
Real estate development has received less scrutiny than real estate investment in terms of appraisal practices and performance measurement. This is despite the inherent uncertainty and financial risks associated with development as an activity. We investigate market practices regarding performance metrics and return expectations both for residential and commercial real estate development in the UK, exploring what is considered as an appropriate return and how this varies according to type and duration of scheme, and method of appraisal used. After examining the literature and the information available on ex-post returns from development activity, results from a survey of real estate developers are reported, supplemented by findings from interviews. The results suggest that the use of traditional residual valuation techniques dominates discounted cash flow models when appraising development projects, particularly among residential developers, while profit-on-cost and profit-on-value are the most popular metrics for quantifying required returns. Unlike NPV or IRR, these metrics do not account for the timing of cash flows, raising questions about the robustness of appraisals in this sector. Such metrics might suffice if required profits are adjusted in ways that are consistent with scheme duration and risks, but it is unclear that this is currently the case.
\end{abstract}

\section{Keywords}

Development; Housebuilding; Profit Measures; Real Estate Appraisal; Required Returns

\section{Acknowledgement}

We gratefully acknowledge the financial assistance of the Research Trust of the Royal Institution of Chartered Surveyors in undertaking this research. 


\section{Performance metrics and required returns for UK real estate development schemes}

\section{Introduction}

Real estate development is often characterised as entrepreneurial and risky, and returns vary with the nature, location and timing of each scheme. Standard texts and professional guidance on the appraisal of developments suggest that this variation is inherent in the nature of the business (see RICS, 2008; Reed and Sims, 2015; Wyatt, 2013). The value of development land and the returns that developers might achieve from schemes can be affected considerably by small changes in factors such as the costs of construction and the value of completed projects.

Perhaps as a result of the uncertainty and volatility of development activity, various methods are used to appraise the feasibility of development projects. Some of these methods are cash flow-based and follow mainstream principles of capital budgeting while others have developed from within the real estate sector. In some models, debt financing is included and itemised in the appraisal while in others it is incorporated within a developer's cost of capital. This variation might explain why practice varies when quantifying the return required from a proposed scheme. Some developers use metrics based on cash profits relative to cost or value, while others prefer to use periodic rates of return such as the internal rate of return (IRR). These differences raise questions about the suitability of different metrics for development appraisal, what an 'appropriate' return is within the context of each metric and how required returns vary depending on scheme characteristics, timing and appraisal method. Estimating required rates of return for investment properties is challenging enough and this exercise benefits from a relatively fulsome supply of research and transaction evidence. Development schemes, which are fewer in number and more heterogeneous, do not have this advantage. Little is understood about developer returns, either in terms of required returns or achieved returns.

The aim of this paper is to improve understanding of the form, extent and variability of development returns. Differences between residential and commercial schemes are discussed and the influences of selected scheme characteristics are considered. However, detailed examples of schemes, whether hypothetical or actual, are not considered and certain types of scheme, such as regeneration projects, are outside the scope of our research. ${ }^{1}$ In terms of structure, the existing academic and professional literature on development returns is reviewed first. Then data published by $\mathrm{MSCl}$ on achieved returns for UK commercial development schemes is examined, as well as corporate performance data for the largest UK housebuilders. Results from a survey of residential and commercial developers in the UK are then presented, which give an overview of the use of development appraisal models and different profit metrics. After this, findings from a small sample of interviews with development consultants, financial institutions and developers of residential and non-residential properties are set out. A final section considers the implications of the study.

Existing information on the ex-post performance of real estate development schemes is fragmented, restricting its use for formulating views about required returns. Meanwhile, the survey results indicate that traditional residual valuation models dominate in the assessment of land values and prospective profits from schemes, particularly among residential developers. Allied to this, the most popular profit metrics among the respondents were profit-on-cost and profit-on-value. The evidence from published appraisals suggests that there is little variation in rates used for such metrics across types of scheme, but survey respondents indicated that market state, planning risk and site-specific factors, inter alia, would change the rate of profit that is required. Although findings relate principally to the UK, there

\footnotetext{
${ }^{1}$ For instance, regeneration schemes might involve public sector partners and receive grants and subsidies that would make their return expectations and outcomes very different to other developments: these variations are beyond the scope of our study.
} 
is a lack of information generally on how real estate developers set and assess required returns. This paper seeks to address this gap.

\section{Literature on developer returns}

\subsection{Models and metrics used}

Academic and professional literature on real estate development identifies residual valuation as an important approach to appraising the value of development sites or expected profit from schemes. ${ }^{2}$ This approach can vary from a basic subtraction of development costs from expected revenues to a periodic cash flow showing expected inflows and outflows from the project. The models used vary in sophistication, with differences in assumptions about the timing of revenues and costs, and in how financing and profit are dealt with (Coleman et al., 2013). Of relevance here is the treatment of profits. In a basic residual valuation, profit is usually expressed as a (percentage) cash margin on value or cost. In a cash flow model, profit is normally expressed as a periodic rate of return.

A cash margin metric such as profit-on-cost does not reflect the duration of a scheme in the same way as a periodic rate of return. A longer project should require a larger monetary return simply by virtue of capital being placed at risk for longer. ${ }^{3}$ A required return expressed as a periodic rate of return will automatically allow for the additional reward needed. In contrast, a cash margin would need manual adjustment on the part of the developer to allow for more profit in this instance. Crosby et al. (2018) illustrate the impact on profit from using a fixed cash margin regardless of the time frame of a scheme; it results in a declining periodic rate of return as the time frame increases. It is an empirical question as to whether and how much developers adjust cash margin metrics in different situations. However, their use makes it difficult to compare development projects of different lengths, and to compare such projects with other investment opportunities whose expected returns are expressed using periodic return rates.

In published appraisals and surveys of UK practice, the cash margin dominates. Marshall and Kennedy (1993) surveyed development companies, financial institutions and advisors. Profit-on-cost was used by $90 \%$ of respondents and $70 \%$ did not use a cash-flow model. Hutchison et al. $(2017: 12,15)$ found that investors used profit or return hurdles for developments that seemed to be "fixed across markets and time periods" and "uncorrelated to the return environment or hurdle rates on standing investments". Coleman et al. (2013) discovered that only one of 19 development appraisals that they studied used a periodic rate of return as the return metric, while London Borough of Southwark found that only two out of 19 appraisals did so in their sample drawn from planning applications (Southwark LBC, 2014). Sayce et al. (2017) studied UK Planning Inspector decisions and found that profit was not expressed as a rate of return in any of the cases examined. The use of cash margins in UK practice has now been reinforced by the UK Government who have specified the profit that developers can 'claim' within the development viability process as $15 \%$ to $20 \%$ of the value of the scheme (MHCLG, 2018). They have not set out any periodic rates of return.

Coleman et al. (2013) note that this approach to development appraisal and to the quantification of a required return does not fit mainstream capital budgeting principles. This is reinforced by Hutchison

\footnotetext{
2 The term 'residual method' may not be recognised in all countries. For the US, Geltner et al. (2007) and Peiser and Hamilton (2012) discuss simple financial feasibility models and discounted cash flow models as methods for appraising developments, both of which use data on revenues and costs to determine a residual land value or expected profit.

${ }^{3}$ Whether longer schemes are riskier than shorter ones because of greater potential variation in their outcomes is a separate question. If they are, both cash margins and periodic return rates should be adjusted accordingly.
} 
et al. (2017), who note inconsistencies with how investment appraisal is conducted in organisations that both develop and invest. However, surveys of non-real estate firms find divergences in project appraisal practices across types of company and types of project analysed. Arnold and Hatzopoulos (2000) surveyed major UK companies and found that most used cash flow techniques, but many supplemented these models with rule-of-thumb techniques and metrics. It was argued that multiple methods helped in cases where NPV rule assumptions might be violated; projects with real options were cited as one such case. Geltner and de Neufville (2018) set out such options in the case of real estate development schemes, which include options to commence, pause and alter schemes in response to economic and market conditions.

Graham and Harvey (2001) surveyed major US corporations and found that most firms used cash flow techniques, with IRR slightly ahead of NPV as the favoured performance metric. Yet the authors found that smaller firms were more likely to use simpler techniques such as payback period and argued that these techniques could approximate optimal decision rules for complex projects with high levels of uncertainty and/or option-like features. Danielson and Scott (2006) found that small firms were far less likely to use cash flow techniques. Gut feel was reported to be the most common approach to project evaluation, then payback, then accounting rate of return and then discounted cash flow. Use of multiple methods was not common, which was linked to personnel constraints. Harjoto and Paglia (2012) examined privately owned US companies and found that the choice of appraisal method was influenced by the approach to business planning in general and the funding sources used by the firm. The most common decision methods were payback, general market analysis and gut feel. $30-40 \%$ of respondents used IRR and discounted cash flow techniques, with more use for projects where cash flow uncertainty was lower.

The literature on corporate project appraisal suggests that firm size is important, with larger firms preferring cash flow appraisal methods and rate of return metrics. However, this literature also notes the limitations of discounted cash flow methods where projects have option-like features or there is great uncertainty around future cash flows. Furthermore, this literature discusses why the target rates or cash margins used in appraisals can be much higher than a firm's WACC. This relates to the desire of firms to focus on the most profitable opportunities in a setting where finances and/or operational capacity are limited. So, if firms cannot do all the positive NPV projects that they identify, they should focus on those that will provide very good returns. These insights provide some support for the use of simple techniques and profit measures in a development appraisal context, but application of such techniques needs to be responsive to scheme characteristics when setting required profits. Whether or not this is the case among real estate development firms is explored below.

\subsection{Quantifying required returns}

There is little theoretical discussion of the required rate of return for real estate development projects. Obstacles to conventional approaches for estimating a target return rate are a lack of information on the performance of development projects and the heterogeneity that surrounds individual projects, which can make it inappropriate to apply a firm-level cost of capital in appraisals. One approach suggested by Geltner and Miller (2000) and extended in Geltner et al. (2007) is to evaluate the cash flows associated with construction costs separately from those associated with revenues, using different target rates for each. Key to this is the assumption that required return rates for completed assets and for construction costs are easier to determine than a required return for the development scheme itself. This approach does not appear to have permeated into industry practice yet.

Empirical evidence on the required returns or profit margins used by real estate developers is sparse. In the UK, published development appraisals provide one source of information. In these appraisals, profit margins are typically quoted relative to total revenues or total costs and so are the equivalent 
of unlevered project return rates in a cash flow context. These appraisals suggest that, for residential development, many housebuilders prefer to apply a margin on value rather than costs, and that these cash margins have been around $20 \%$ in most cases, although a fair number have been below $20 \%$. On the rare occasions that IRR was used, this was either $15 \%$ or $20 \%$ per annum. Where profit-on-cost was used, this ranged from $15 \%$ to $22.5 \%$ (see Coleman et al. 2013; Southwark LBC, 2014; Crosby and Wyatt, 2016; Crosby et al. 2018). These figures are all gross of interest and tax. Meanwhile, some UK housebuilders report targets for development (as opposed to corporate) performance in their end-ofyear financial reports. For example, Barratt Developments set a target gross margin (on revenue) for new sites of $23 \%$ in their 2018 report. ${ }^{4}$ However, the disclosure of such targets is sporadic.

Savills (2017) suggests a target profit of $20-25 \%$ of gross development value depending on the scale and type of developer, which comprises allowances for both profit and overheads. They argue that this margin does not take account of any abnormal costs, and that target returns will be at the lower end of this range for small, low density and less constrained sites, and at the higher end for large, complex sites, particularly brownfield sites. They also state that, if an internal rate of return is used, it should be a minimum of $25 \%$ per annum, though the basis for this is unclear. In evidence to a UK Government inquiry into housebuilding (Letwin, 2018), David Jackson, Head of Planning, and Emily Williams, Senior Researcher, at Savills suggested that developers sought a profit margin of $15-20 \%$ of gross sale value. Similarly, as part of the same inquiry, a round table meeting of developers agreed that a typical operating margin on large sites would be $20 \%$.

IPF (2015) compares required returns for development of residential 'build-to-sell' schemes in the UK versus 'built-to-rent' where large-scale residential accommodation is developed and then held as an investment on an ongoing basis. ${ }^{5}$ IPF states a required IRR of 10-12\% per annum for the development of residential investments versus $15-20 \%$ per annum for conventional residential schemes. ${ }^{6}$ The IRRs are based on gross development value and the direct costs of the development including actual or notional land purchase, but ignoring finance. This report is notable for stating target rates of return, which raises the question as to whether the different types of organisation discussed (housebuilders versus institutional investors) use different methods and hurdles. There is no comparable information for commercial property schemes to our knowledge. Marshall and Kennedy (1993) found that $60 \%$ of commercial real estate developers required a profit of $15 \%$ to $18 \%$ of development costs, $30 \%$ wanted $18 \%$ to $21 \%$ and $10 \%$ required $12 \%$ to $15 \%$ of costs, but this evidence is now very dated.

\subsection{The impact of risk on required returns}

Some of the variation in required returns reported by the studies above is likely to reflect differences in risk between projects. There is some literature on the sources and modelling of risk in real estate development, but it is unclear from this literature whether risk is priced consistently or effectively in practice. Byrne (1996) notes some of the main sources of uncertainty in the property development process, which create risk in the form of variation in the potential financial outcomes. The sources of uncertainty include real estate market conditions, production costs and project timings. Carmona et al. (2003) identify similar factors in their discussion of housebuilding. Within these broad headings, further factors could be identified for specific types of site and scheme. For example, the development of large, low density residential schemes may take several years and be organised into several phases, which will influence the risks faced but also provide opportunities to manage risk.

\footnotetext{
${ }^{4}$ As reported in Barratt Developments Plc Annual Report and Accounts 2018, pages 8-9.

${ }^{5}$ In other words, the equivalent of multifamily residential investments that are common in North America and elsewhere where institutional investments in the residential sector is more established.

${ }^{6}$ In comparison, Peiser and Hamilton (2012) cite $12-15 \%$ p.a. unlevered IRRs for multifamily residential schemes in the US.
} 
Developers will need to accept some risks as part of the development process but can mitigate others. If risk mitigation strategies are adopted, then this should impact on the required return rate or level of profit demanded. There is a limited literature on the mitigation of risks in development. Fisher and Robson (2006) surveyed UK office developers and their response to risk. They investigated a range of risk mitigation strategies including phasing of development, incorporating a mixture of land uses and using mechanisms to reduce the duration of development projects, but make little specific comment on how required returns or profits might change as a result of adopting such strategies. Adams and Watkins (2002) also note some risk mitigation strategies for residential development, including land banking by larger housebuilders and the use of options or conditional contracts for land purchases to mitigate planning-related risks.

Wiegelmann (2012) reports findings from a 2005 survey of 69 European developers, around half being trader/developers and the other half investor/developers. They included 63 who undertook office development and 47 who undertook residential as all or part of their development portfolio. Another 47 have a risk management committee of some form or other. The study looked at both company level and project specific risks, and the major project specific risks identified were the development conception, location, disposal of developed assets, first letting and planning and environmental issues. Yet, this study did not identify what project-specific risk-mitigation strategies these companies adopt, concentrating instead on the risk management process.

From a survey of 24 listed mixed-type development companies in Australia (but all undertaking some residential development), Newell and Steglick (2006) identified 34 risk factors across five stages of development. Actions to mitigate risk at the preliminary and contract negotiation stages included use of conditional contracts, detailed viability assessments, and retaining the option to halt, alter or delay the scheme. Using corporate rather than project-specific finance was also mentioned. Contract nonperformance penalties and insurance policies were highlighted as risk mitigation strategies at the construction stage. Post-construction risk mitigation steps included pricing strategies, incentives, contingency marketing plans, pre-sales and pre-letting activity, and the use of corporate branding.

The survey of developers undertaken for this paper investigated similar risk mitigation strategies and attempted to identify the way in which required returns would change (if at all) in response to the use of such strategies. The paper focuses on commercial, residential and mixed-use development projects rather than area-wide regeneration schemes that may involve government funding and public sector participation. We investigated how developers perceived phasing, scheme duration, mix of land uses, and retention versus sale of completed assets to affect their estimate of the target return rate. Postcompletion evaluation of projects does not seem to feature strongly as a risk mitigation tool (for future projects) in the literature, but this was also included in the survey.

\subsection{Summary}

This review suggests several gaps in knowledge that this study attempts to address. First, it suggests that cash metrics and non-cash flow methods of appraisal are common in UK practice, but this is based primarily on observation of residential development appraisals. Furthermore, much of this evidence has little to say about whether and why required return or required profit hurdles vary between sites and schemes, the Savills (2017) publication being an exception in this respect. Therefore, the analysis below attempts to establish whether residential and commercial development appraisal practices do differ and what guides the quantification of a required return or required profit margin in each case. This is prefaced by an examination of the evidence on ex-post return rates to understand whether and how delivered returns to different types of development scheme have varied over time. 


\section{Examining ex-post return rates for development schemes}

There is some evidence of achieved returns on real estate development projects in the UK. Following an initial study in 2010 (IPD, 2010), Investment Property Databank (IPD) published on an annual basis the achieved IRRs for development schemes completed by their investment clients. These schemes were predominantly for commercial rather than residential land uses. $\mathrm{MSCl}$ then acquired IPD and became the main provider of performance benchmarks for private real estate assets, but they ceased publishing development project IRRs in 2015 (the last set of IRRs relating to schemes finished in 2014). Analysis here focuses on returns reported up to that point.

The $\mathrm{MSCl}$ database of investment property is constructed from financial records for properties held by major investors such as financial institutions, pooled funds and listed property companies. At end2014 , it was based on around 10,000 properties with a capital value of over $£ 150$ billion. It is often characterised as relating to the best property in the best locations, but the contributing investors hold significant proportions of secondary properties, many of which have depreciated over time, requiring recurrent expenditure on maintenance, improvement and development totalling over $£ 20$ billion in 2014. Yet, although this database includes prime and secondary properties, the locations that it covers do not constitute a representative sample of all locations in the UK (see Byrne, Jackson and Lee, 2013). As such, the reported returns might not be indicative of commercial development returns across the UK, but they are based on a large sample of schemes.

MSCl identified developments (including redevelopments and refurbishments) using a ratio of capital expenditure to asset capital value within a given timeframe. IRR was then calculated using unlevered project cash flows, before interest and tax, and either purchase / sale prices or valuations for the site and completed asset(s). Figure 1 (based on IPD, 2015) charts median IRR in each year from 3,876 UK developments completed between the start of 1983 and the end of 2014. The return is the annualized IRR calculated as at the year of completion. The mean of this time series is $5.5 \%$, with a median of $6.5 \%$ and a standard deviation of $10.3 \%$. These numbers, together with Figure 1, indicate that there is much variation over time in the 'typical' return achieved from development projects. This variation is unsurprising, but the mean and median IRR are below the mean and median total return from standing investments over the same period, at $9.6 \%$ and $10.6 \%$ respectively (also based on IPD, 2015).

\section{INSERT FIGURE 1 HERE}

The figures are not strictly comparable, as returns from standing investments are not computed in the same way, but the findings are surprising. Real estate development is perceived to be a more volatile activity than owning existing investment properties, justifying higher returns, though this conventional view has been challenged by some recent research (Geltner, Kumar and Van de Minne, 2018). On this evidence, ex-post development return rates seem poor relative to the performance of UK real estate investments.

The comparison of developments and standing investments is complicated by the fact that the data cover different types of development activity; construction of new buildings, redevelopment and refurbishment of existing assets, and pre-funding of development schemes. Thus, the finding above may be a characteristic of the dataset and not an indication that development is a low risk / low return business. ${ }^{7}$ Figure 2 shows the mean and standard deviation for IRR series that relate to different forms of development activity and different use types. On average, redevelopment was the most profitable form of development in this sample, but with more volatility through time in the typical outcome. For property type, retail schemes performed best, while office schemes performed the worst. The under-

\footnotetext{
${ }^{7}$ Furthermore, figures for all developments are somewhat skewed towards the office and new build outcomes, as these project types were most numerous in the sample.
} 
performance of office schemes is marked. It appears to be driven by schemes completed a year or two after a downturn; for example, in 1992 to 1994, in 2002 to 2004 (after the dot-com bubble burst in 2000) and in 2009 to 2011 . This suggests it is a function of the development cycle where schemes are planned in the upturn but then delivered in the downturn, and office market downturns in the UK were more pronounced historically than for other commercial property types.

\section{INSERT FIGURE 2 HERE}

One other available split of the data relates to achieved IRR p.a. by length of scheme. The means and standard deviations for these series are shown in Figure 3. The average outcome appears similar for developments up to three years in length but reduces thereafter as development timelines increase. Yet the standard deviation also reduces, which would be consistent with a rational risk-return tradeoff, though it is unclear that longer projects should be less volatile in their outcomes, unless variations are reduced by other factors such as phasing. A lower rate of return would also be the expected outcome if development appraisals and prices paid were based on fixed cash margins rather than periodic rates of return (see Crosby et al. 2018). However, an important caveat is that the sample sizes for longer projects are smaller and may be subject to survivor bias; $79 \%$ of the projects on which these figures are based being three years or less in duration.

\section{INSERT FIGURE 3 HERE}

IPD (2010) sets out in more detail some of the definitions and assumptions relating to this data. There are difficulties in measuring development performance. For example, there are issues with defining both commencement and completion dates, particularly where sites or assets are notionally sold from and to investment portfolios. The basis for the value of a development site (existing use value or with development potential) is not known and the classification of a scheme to a specific use type such as office or industrial obscures the extent to which other land uses are present. Lack of access to scheme level data limits the scope for multivariate analysis and there is not, to our knowledge, information on site characteristics, funding arrangements or target returns in the data. Nonetheless, the results raise some interesting questions. For instance, if the level and variation in returns to development reported here were replicated across the UK development industry, it would raise significant questions about the risk and return of real estate development relative to investment.

In comparison, there is little information about achieved returns for residential development schemes. Some inferences are possible from the financial performance of housebuilders, though this relates to corporate rather than scheme performance. Data on corporate performance is easily obtainable, but it has some important limitations because it is difficult to separate out the performance that is purely attributable to development activity from that which might arise from other activities such as land promotion or holding sites for future development. Nonetheless, Figure 4 presents average operating profit margin and average return on capital for the seven largest UK housebuilders by revenue. ${ }^{8}$ Both profit margins and return on capital increased through the late 1990s and early 2000 s, dropped in the mid-2000s and dropped further with the onset of the financial crisis in 2007-08. Performance has improved steadily since then and operating profits of the major housebuilders are now above $20 \%$ of revenue. This illustrates that housebuilding is cyclical like other forms of real estate development, but disguises differences between firms operating in the residential development sector. ${ }^{9}$

\footnotetext{
${ }^{8}$ The firms were Barratt Developments, Bellway, Berkeley Group, Bovis Homes, Persimmon, Redrow and Taylor Wimpey. Figures are based on the financial year of the company, which is not the same in each case owing to the use of different financial year-end dates.

${ }^{9}$ However, Adams et al. (2009) find that profit margins for residential development remain relatively stable over time and that it is land bid prices that vary with market shifts and changes in planning policy.
} 


\section{INSERT FIGURE 4 HERE}

Property Data (2018b; 2019) rank the top 200 UK housebuilders each year according to turnover and list both turnover and pre-tax profit, enabling comparison of operating profit margin by size of firm within this group. Figure 5 illustrates that six housebuilders had annual turnovers of more than $£ 2$ billion in the period 2017-2019 and recorded average profit margins of over $20 \%$. The returns made by these top six firms are not repeated across other size bands, with the smallest firms $(<f 50 \mathrm{~m}$ turnover) on average achieving less than half the margin of the top six firms. This suggests that profits across the housebuilding industry decline as firm size reduces, though the decline is uneven. However, this does not indicate the sizes or types of scheme that are more profitable, and firm-related factors may be important as well. Wellings (2006) examines reasons for and patterns in UK housebuilder profitability, noting the potential economies of scope for larger firms from being able to develop and market multiple schemes at any one time. ${ }^{10}$

\section{INSERT FIGURE 5 HERE}

In summary, data on ex-post returns to development projects is variable in its nature and depth. For commercial real estate schemes, the $\mathrm{MSCl}$ dataset is potentially a rich resource, but publication of the aggregate series based on such data has ceased. The data published historically suggest some patterns in relation to type, size and length of scheme, but it is difficult to read any lessons from this in terms of setting ex-ante return targets. In fact, the magnitude of historical achieved returns and the patterns in relation to scheme type and length raise as many questions as answers. Meanwhile, for residential schemes, there is no comparable data source and only general patterns in profitability over time can be observed from corporate financial data. Therefore, to better understand appraisal practices, profit metrics and required returns used by UK developers, the remainder of this paper reports results from survey and interview research.

\section{Survey of UK development appraisal practices}

\subsection{Survey design}

The dearth of published information on the profitability of real estate development prompted further investigation of how development appraisals are conducted in practice and how profitability is being benchmarked in the UK real estate development sector. The investigation proceeded by way of both questionnaire and interview-based research. The questionnaire exercise sought to gather information from developers on the chosen methods and metrics for appraisal of sites and schemes. To encourage completion, the questionnaire did not ask directly about the target returns or profit margins used by organisations, but it did ask about factors affecting the returns required from different schemes. The interviews then sought to complement the questionnaire by investigating some of the findings in more depth, including the required return or profit margin if a typical rate was used by interviewees and their firms.

For the questionnaire survey, the total population of UK real estate developers was taken to be all the organisations listed in The UK Commercial Developers Directory and The UK Housebuilders Directory, 2018 Editions, published by Property Data (2018a, 2018b). UK General Data Protection Regulations do not permit email addresses for named persons to be included in the directories, so questionnaires were sent to company email addresses. All entrants were contacted apart from regional offices of the same company (i.e. surveys were sent to head offices only) and 50 entries from each directory where

\footnotetext{
${ }^{10}$ However, he does not find empirical evidence for greater profitability among larger firms at that time.
} 
email addresses were not available. The questionnaire was first piloted with 50 developers, 25 from each directory. For the main survey, 1,271 commercial developers and 1,450 residential developers were contacted, a total of 2,721 recipients. 160 developers responded, a response rate of $6 \%{ }^{11}$ The analysis and reporting of responses was conducted in a manner that preserved the anonymity of the respondents.

The absolute number of responses enabled disaggregation by type of developer; whether they were solely residential in scope or not solely residential (encompassing purely commercial developers and developers of both residential and commercial sites). This classification was based on the information supplied by respondents and not the directory from which a respondent was sampled. Most of the responses received appear to be from smaller companies. 97 responses (55\%) were from residential developers, 37 responses (21\%) from commercial developers and 31 responses (18\%) from developers of mixed-use schemes. 11 respondents (6\%) specified their main development activity separately and these responses included healthcare and retirement living (4 responses), student accommodation ( 2 responses) and leisure (1 response).

Most of the responses to the questionnaire were from smaller companies. We received ten responses from companies that were ranked in the top fifty residential and commercial firms, which represents $20 \%$ of that sub-group, leaving 150 responses from smaller firms, a response rate of $5.6 \%$ from that sub-group. This breakdown is representative of the composition of the real estate development industry in the UK, which is dominated by small firms. For example, focusing on residential developers, 1,450 were listed in the directory but only 256 of these had published financial information. For those 256 developers, total turnover in the latest financial year was $£ 38.1 \mathrm{bn}$ and the top 50 were responsible for $£ 33.6 \mathrm{bn}$ or $88 \%$. In the UK there is a very large number of small residential developers responsible for around $12 \%$ of annual turnover. The questionnaire responses reflect this. It is difficult to conduct the same analysis of commercial developers as their turnover often includes revenue from other (usually investment) activity. The dominance of large firms in terms of turnover motivated the focus on larger companies for the interview survey.

\subsection{Questionnaire findings}

Turning to the questionnaire findings, an initial question focused on how schemes were appraised at the outset of the development process, prior to site acquisition or other financial commitment. 118 respondents (64\%) said they used the residual method and $56(30 \%)$ used a cash flow to appraise the profitability of, or land value for, a development opportunity (the choice was not mutually exclusive). 12 respondents (6\%) described their appraisal technique in their own words. Two emphasised the importance of using comparable evidence as a check and one stated a range of techniques, including a residual valuation, market comparison, cash flow modelling, forecasting and sensitivity analysis. One respondent stressed how they already owned sites that were brought forward for development, while another (a Registered Social Landlord) factored in the availability of grant funding for social housing when appraising financial feasibility.

Figure 6 compares the responses of pure play residential developers with non-residential developers and developers of mixed-use projects. It shows that the former favoured conventional residual techniques over cash flow techniques.

\section{INSERT FIGURE 6 HERE}

\footnotetext{
11 The response rate might seem low, but it is not out of line with surveys of corporate financial practices. For example, the response rate for Graham and Harvey (2001) was $9 \%$ and the response rate for Jagannathan et al. (2016) was $3.4 \%$.
} 
One of the characteristics of the conventional residual valuation model is that finance is included as a project-related cost in the appraisal, whereas cash-flow models normally separate project cash flows from finance costs, so that the impact of a specific funding arrangement on the developer's return can be identified (see Coleman et al., 2013). The survey therefore asked whether and how finance costs were incorporated in development appraisals, with the results shown in Figure 7. Most responses (77 or $46 \%$ ) indicated that finance was included as a cost in a residual valuation, which is consistent with the assumptions of this technique, while a third of responses (61 or 37\%) indicated that finance was included in the cash flow appraisal. So, most developers in this sample $-83 \%$ of responses - do not undertake a pre-finance project appraisal at the initial feasibility stage; finance is an integral cost in such appraisals regardless of whether it should be included.

\section{INSERT FIGURE 7 HERE}

The questionnaire also asked how developers benchmark the profitability of development schemes. Respondents could indicate the frequency with which they used various metrics. Table 1 summarises the results. The pattern is marked in terms of preference for cash-based metrics such as profit on cost or profit on value versus return-based metrics such as project or equity IRRs. It is also interesting that metrics concerned with rewards to developer equity are not well used, but this might reflect that the financial structure for a scheme is unlikely to be known at the feasibility stage. Three respondents cited development yield as a profit benchmark, which is preferred when schemes are to be retained as investments or as operational assets like social housing. One respondent mentioned that NPV was an important output, another used profit as a cash sum only (not scaled to costs or values) and another mentioned cash on cash return, particularly in relation to commercial redevelopment opportunities.

\section{INSERT TABLE 1 HERE}

Cross-tabulating these results with type of developer reveals that pure play residential developers are less likely to use project IRR. This is consistent with the earlier finding regarding their preference for residual over cash flow techniques. Of 25 respondents who never used project IRR, 19 of them were residential developers, whereas the other six did commercial or both types of development. All types of developer were as likely to use profit-on-cost as a metric as project IRR, but residential developers were more inclined to use profit on value as a benchmark for financial viability.

Respondents to the questionnaire were asked to score a range of factors from 0 to 100 to understand which factors might be more important when setting a required profit or return rate. Table 2 sets out the results. Market state, planning status, site-specific risks and location scored more highly than the land use or size of scheme. Interestingly, operating leverage (the ratio of costs to value) was only scored as moderately important. Projects that have high operating leverage have high costs relative to revenue and, as a result, a residual land value that is small and more sensitive to changes in either revenues or costs. Arguably, developers should require a higher rate of return where the operating leverage is high because the volatility in potential outcomes is greater, but this does not seem to be reflected strongly in appraisal practice.

\section{INSERT TABLE 2 HERE}

Questionnaire respondents were then asked how the target return rate or profit metric would change in response to some specific factors. These factors were the duration of the scheme, whether it was to be phased or not, whether the scheme was to be sold or retained and whether it was single use or mixed use. Figure 8 shows that, for development length, respondents were equally divided between increasing the profit target for longer developments or not adjusting it at all. One explanation for this finding could be that those developers using cash flow techniques keep the target rate static because 
it allows already for the time effect, while those using conventional residual techniques need to raise their profit target to maintain a similar periodic return rate (see Crosby et al., 2018). However, crosstabulation of the responses showed that this was not the case; there was no significant difference in answers when responses were categorised in this way.

\section{INSERT FIGURE 8 HERE}

Only two respondents indicated that they would decrease their target for longer projects. Thus, the approach to setting targets contrasts markedly with the pattern observed in ex-post returns from the $\mathrm{MSCl}$ dataset whereby longer schemes delivered lower IRRs on average. Two respondents suggested reasons why they would increase IRR targets for longer schemes. The first mentioned exposure to cyclical risk and the second argued that it would increase to allow for a longer period of borrowing. One respondent noted that "it might increase, but in practice, this is often reflected in higher costs which are spread over a longer period." Another respondent indicated that the decision on whether to change the target return was more of a site-specific matter and another stated that "we more often look at the profit based on achieving a certain IRR."

For phased schemes, most respondents (71 or $60 \%$ ) would not alter their target profit or return rate, while $17(14 \%)$ stated that it would increase and $15(13 \%)$ that it would decrease. One respondent suggested that the adjustment depends on the reasons for phasing, while another noted that phasing might mean reduced finance costs, but any change to target profit would not be huge. One person stated that: "phases de-risks from my perspective (assuming that they are severable). If not severable, it probably increases risk (hence margin increases). Also, apply higher margin to later phases as there is more uncertainty in assumptions and viability (whether it will even happen)." Three respondents to this question emphasised the importance of infrastructure costs. If these were significant and were to be incurred in the early part of a project, then this would influence the target profit benchmark.

Responses were more mixed for whether targets would change for schemes that were to be retained as investments. ${ }^{12} 52$ respondents (44\%) would not alter the target profit, but $30(25 \%)$ said that they would decrease it and $11(9 \%)$ said they would increase it for schemes that were to be retained. Comments provided by several respondents provide some explanations for the responses. One stated that target profit would not change "because it is still the development risk... The two types of risk should not be mixed up and in practice are treated differently hence transferring between development portfolios and investment portfolios." Similarly, another respondent stated that "profit in development phase would need to be greater than investment due to risk profile."

Figure 9 illustrates that responses regarding targets for mixed use schemes varied markedly. While most developers stated that they would not alter their target profit or return rate to reflect mixeduse, there were 29 respondents who would increase the return and 13 that would lower it. Several respondents stressed that it depended on the specific nature of the scheme, the mix of uses and the risks involved. One respondent noted that they worked with a development partner when the scheme was mixed-use; "we would only deliver the residential element therefore our profit would remain consistent. On mixed use scheme we would choose partner to deliver non-residential element they would do separate viability and determine own level of profit... depending upon use." This identifies the fact that a mixed use scheme could be delivered by a group of specific commercial or residential developers. Another suggested that the ability to pre-sell to reduce risk profiles was important and another that it depended on the use classes being developed within the mix and the timing of delivery to the market. There is no consensus view on whether undertaking a mixed-use development is riskier or less risky than development of a single use type.

\footnotetext{
12 It should be noted that the retention of completed schemes as investments is not usually undertaken by residential developers and this might have affected responses to this question.
} 


\section{INSERT FIGURE 9 HERE}

The final question concerned the extent of analysis of schemes once they were completed. Results are set out in Figure 10. Around $65 \%$ of the respondents claimed that they always or usually back-tested the appraisal against project outcomes, leaving over $20 \%$ of respondents undertaking this exercise occasionally and around $10 \%$ never back-testing the appraisal

\section{INSERT FIGURE 10 HERE}

The questionnaires findings show that basic residual valuation techniques are still very common in UK practice when assessing the feasibility of development schemes, particularly in relation to residential development. Cash margin-based measures such as profit-on-cost and profit-on-value dominate in terms of benchmarks for financial feasibility and these are popular even in organisations that rely more on cash flow appraisal techniques. Inclusion of finance in appraisals remains common and profit or return rate targets are not adjusted consistently in response to changes in scheme length, phasing or the intention to retain assets on completion. However, the respondents indicated that the factors influencing risks, and thus target returns or profit levels, can be complex in such cases.

\subsection{Interview findings}

To obtain further insights into appraisal practices and required returns, interviews were undertaken with developers and other stakeholders, with a focus on larger developers and their advisers. Eight interviewees were selected from different types of organisations involved with real estate development using purposive sampling. Interviewees included individuals working for the following types of organisation: a large national house builder; a leading investment institution; a major mixed residential and commercial property company with separate land promotion, development and construction arms; a large development consulting company; a small development consulting company; a land promotion company; an urban regeneration organisation; a major property company. Information was provided conditional on confidentiality for the respondents and their organisations.

Larger companies dealing with larger schemes tended to use more sophisticated cash flow-based models. Nonetheless, the interviews identified that many developers would be reluctant to put a great effort into appraisals at the early stages of a development when they were only assessing the feasibility of a proposed scheme. This is consistent with arguments in the corporate finance literature around the use of basic appraisal techniques in situations where uncertainty of cash flows is greater, and more option-like features are present. Meanwhile, the land promoter tended to use a more basic residual model since they did not plan to carry out developments themselves but focused on what developers would bid for sites. Hence, they were reluctant to use cash flow models that might require detailed inputs, such as costings from consultants.

However, this perspective may be less true for organisations that are investors and developers, and who hold development opportunities within their investment portfolios already in the form of existing built assets ready for redevelopment or refurbishment. The major investment institution interviewed used cash flow modelling as part of any portfolio review of assets. This would include the feasibility of alternative strategies for a building, of which a major refurbishment or redevelopment would be one, as would a potential change of use.

The interviewees supported the findings on the benchmark rates of return, suggesting that profit-oncost or profit-on-value ratios tended to be the primary benchmark, even for larger developers, and 
even when cash flow techniques were used to generate internal rates of return. Several interviewees quoted required target rate, profit-on-cost or profit-on-value ratios. The larger organisations did not follow the Savills (2017) contention that profit ratios and required IRRs were similar in magnitude. IRR expectations of $10 \%$ p.a. for commercial or mixed-use projects longer than five years were matched to a $20 \%$ profit-on-cost target by several interviewees. Two suggested that this would change to $15 \%$ $20 \%$ IRR and $20 \%-25 \%$ profit-on-cost for sites without planning consent. An IRR of $10 \%$ or more with a profit-on-cost of $15 \%$ was mentioned by one interviewee as the target on a mixed-use town centre development scheme in the South-East of England. Targets of $23 \%$ to $30 \%$ profit-on-value were cited for housebuilders, higher than the figures noted in the literature review.

The impact of time on returns was discussed in some detail within the interviews. These discussions suggested that, though IRR was an important metric in analysing developments, cash margins were kept relatively static in relation to the duration of the scheme. The interviewees were dealing with longer, larger developments in the main, so the impact of a scheme taking longer was perhaps not as crucial to the return as it would be for smaller, shorter schemes. Yet, although the developers aspired to constant IRR targets, they also had targets for their profit-on-cost or profit-on-value metrics that did not change much with scheme duration. Meanwhile, interviewees in organisations that retained developments on completion agreed that the development phase was benchmarked differently to the investment portfolio and therefore return expectations varied.

Finally, the interviewees representing larger organisations stated that they looked back and compared scheme outcome against their expectations and targets, some in more detail than others. However, the results of this research show that this certainly is not universal practice.

\section{Conclusions}

This study sought to improve understanding of the form, extent and variability of returns to real estate development. The focus was placed on the UK real estate development sector, but there is a general lack of research in this area. The objective was to bring the fragmented information on development profitability together and extend it via primary research to improve knowledge of how appraisals are conducted and how profitability is assessed in this sector. The literature review sought to place these findings within the context of general project appraisal practices.

Information on ex-post return rates was examined as one potential source for shedding light on what developers should expect in terms of returns from different types or lengths of project. Questionnaire and interview research complemented this by surveying different types of developer from across the UK real estate industry. The non-residential development sector is more challenging to analyse owing to the interplay between investment and development activity that typifies this sector, whereas housebuilders tend to focus on development for sale. Hence, both residential and non-residential developers were surveyed, while the interviews included land promotion companies and investment institutions as well. This approach enabled us to gather information from across the UK development sector, although we acknowledge that producing definitive findings is difficult due to the fragmented nature of the sector. The challenge was to obtain a representative sample from a sector that includes many small firms but where output is dominated by a few very large firms.

The results revealed differences in development appraisal practices between pure residential versus commercial or mixed activity developers, and between large versus small organisations undertaking real estate development. Larger developers and commercial real estate developers tended to adopt more sophisticated cash-flow appraisal models while smaller firms and housebuilders often used more basic residual valuation techniques. A similar distinction existed regarding type of performance metric 
used. Firms using residual techniques tended to favour profit-on-cost or profit-on-value metrics, while those using cash flow appraisals applied periodic rates of return. However, the latter often referred to cash margin metrics too when assessing the financial viability of a scheme. The inclusion of finance in appraisals remains common and back-testing of appraisals varies, with some firms appearing to do this routinely while others do so rarely. Yet, without back-testing, it is hard to establish which aspects of projects caused realised returns to vary from initial expectations.

Interviewees identified rates of return or profit margins that they used in appraisals. As per the survey findings, residential developers preferred cash margin metrics and $20 \%$ profit-on-cost was mentioned for sites without significant risks such as planning and $25 \%$ for those with additional risks. This implies a profit-on-value of around $15 \%$ to $20 \%$, the figures set out in the UK Planning Practice Guidance on Viability. ${ }^{13}$ We did not find much evidence for a more nuanced approach to variation in cash margins for projects of different lengths, locations or scheme-specific factors. Larger commercial developers, using cash flow appraisals and developing longer schemes, quoted per annum IRR targets of around 10-12\%; this reconciles with requiring higher cash returns for longer projects. Crosby et al. (2018) found that IRRs and profit-on-cost were similar in magnitude for projects around two years in length, with shorter projects producing higher IRRs and longer projects producing lower IRRs from a static profit-on-cost target. There was comment in the interviews about target returns increasing for longer projects and this would seem logical for cash metrics in order to maintain a constant IRR.

Data on achieved returns revealed some inconsistencies. The best available source on ex-post scheme performance are the series that were published by $\mathrm{MSCl}$, although there are notable issues with this dataset. It appears that commercial real estate investment returns in the UK, on average, have been nearly double those from developments. If that finding held across the UK development industry, it would be very significant since it contrasts with the long-held perception of the relative risk of each activity and the associated return requirements applied within appraisals. Therefore, returns achieved by different schemes and the factors affecting such returns warrant more research, though accessing appropriate data is difficult. The $\mathrm{MSCl}$ series also suggest that achieved per annum IRRs reduce as the project gets longer. This does not appear to correspond with how target returns are determined in relation to scheme length as revealed by the survey and interviews, though it may be consistent with the use of fixed cash margins, which would cause expected periodic return rates to decline as scheme duration increases. However, we note that the findings may be influenced by data limitations.

Development appraisal has received less attention than investment appraisal in academic literature and professional guidance until recently. Interest in development appraisal has been stimulated in the UK by changes in the planning policy environment that placed financial viability appraisals at the heart of plan-making and planning decisions (Crosby et al., 2013; McAllister et al., 2013). So far, this has not brought about the same evolution in valuation techniques and benchmarking practice as seen for real estate investments (Crosby and Henneberry, 2016). Our study has identified assumptions and models that are used currently in UK practice when developers seek to appraise land value or the potential profits from a scheme. The models and metrics used remain limited in their sophistication, which may reflect the difficulties calibrating more complex models when precise details for a scheme, its timings and the appropriate inputs are unknown. The continued dependence on basic cash margin metrics as benchmarks is surprising, but the investment appraisal story shows that improvements can take a long time to assimilate into practice.

\footnotetext{
${ }^{13} \mathrm{https}$ ://www.gov.uk/guidance/viability. This choice of profit target in official guidance is perhaps unsurprising. In the absence of much analysis of development returns, it suggests that guidance has followed the rule of thumb for an appropriate return that is adopted by the UK development industry.
} 


\section{References}

Adams, D. and Watkins, C. (2002) Greenfields, Brownfields and Housing Development, Blackwell, Oxford.

Adams, D., Leishman, C. and Moore, C. (2009) Why not build faster? Explaining the speed at which British house-builders develop new homes for owner-occupation. Town Planning Review, 80(3): 291-314.

Arnold, G. C. and Hatzopoulos, P. D. (2000) The Theory-Practice Gap in Capital Budgeting: Evidence from the United Kingdom, Journal of Business Finance \& Accounting, 27(5-6): 603-626.

Byrne, P. (1996) Risk, Uncertainty and Decision-making in Property Development, Second edition. London, E \& FN Spon.

Byrne, P., Jackson, C. and Lee, S. (2013) Bias or rationality? The case of UK commercial real estate investment. Journal of European Real Estate Research, 6(1), 6-33.

Carmona, M., Carmona, S. and Gallent, N. (2003) Delivering New Homes: Processes, Planners and Providers, London, Routledge.

Coleman, C., Crosby, N., McAllister, P. and Wyatt, P. (2013) Development Appraisal in Practice: Some Evidence from the Planning System, Journal of Property Research, 30(2), 144-165.

Crosby, N., Devaney, S. and Wyatt, P. (2018). The implied internal rate of return in conventional residual valuations of development sites. Journal of Property Research, 35(3): 234-251.

Crosby, N. and Henneberry, J. (2016) Financialisation, the valuation of investment property and the urban built environment in the UK. Urban Studies, 53(7), 1421-1441.

Crosby, N., McAllister, P. and Wyatt, P. (2013) Fit for planning? An evaluation of the application of development viability appraisal models in the UK planning system, Environment and Planning B, 40, 3-22

Crosby, N. and Wyatt, P. (2016) Financial viability appraisals for site-specific planning decisions in England, Environment and Planning C: Policy and Space. 34(8), 1716-38

Danielson, M. G. and Scott, J. A. (2006) The Capital Budgeting Decisions of Small Businesses, Journal of Applied Finance, 16(2): 45-56.

Fisher, P. and Robson, S. (2006) The Perception and Management of Risk in UK Office Property Development, Journal of Property Research, 23(2), 135-161.

Geltner, D. and de Neufville, R. (2018) Flexibility and Real Estate Valuation Under Uncertainty: A Practical Guide for Developers, Wiley-Blackwell, Chichester.

Geltner, D., Kumar, A. and Van de Minne, A. M. (2018) Riskiness of Real Estate Development: A Perspective from Urban Economics and Option Value Theory, Real Estate Economics, Forthcoming.

Geltner, D. and Miller, N. (2000) Commercial Real Estate Analysis and Investments, South-Western University Press.

Geltner, D., Miller, N., Clayton, J. and Eichholtz, P. (2007) Commercial Real Estate Analysis and Investments, 2e, South-Western Cengage Learning. Ohio, US.

Graham, J. R. and Harvey, C. R. (2001) The theory and practice of corporate finance: evidence from the field, Journal of Financial Economics, 60, 187-243.

Harjoto, M. A. and Paglia, J. K. (2012) Cost of Capital and Capital Budgeting for Privately-Held Firms: Evidence from Business Owners Survey, Journal of Accounting and Finance, 12(5): 71-85.

Hutchison, N., Lizieri, C., MacGregor, B., Mansley, N., Portlock, R., Schulz, R. and Zhao, Y. (2017) An Investigation of Hurdle Rates in the Real Estate Investment Process. London: Investment Property Forum.

IPD (2010) IPD Development Performance. London: Investment Property Databank.

IPD (2015) UK Annual Property Digest 2014. London: Investment Property Databank.

IPF (2015) Mind the viability gap: Achieving more large-scale, build-to-rent housing. London: Investment Property Forum.

Jagannathan, R., Matsa, D. A., Meier, I. and Tarhan, V. (2016) Why do firms use high discount rates? Journal of Financial Economics, 120 (3): 445-463. 
Letwin, O. (2018) Independent Review of Build Out: Final Report. Ministry of Housing and Local Government. London, UK. October 2018.

Marshall, P. and Kennedy, C. (1993) Development Valuation Techniques, Journal of Property Vaulation and Investment, 11 (1): 57-66.

McAllister, P., Wyatt, P. and Coleman, C. (2013) Fit for policy: some evidence on the application of development viability models in the United Kingdom planning system, Town Planning Review, 80 (4), 495-522

MHCLG (2018) Guidance: Viability. Ministry of Housing, Communities and Local Government. https://www.gov.uk/guidance/viability\#viability-and-plan-making

Newell, G. and Steglick, M. (2006) Assessing the importance of property development risk factors. Pacific Rim Property Research Journal, 12 (1): 22-37.

Peiser, R. B. and Hamilton, D. (2012) Professional Real Estate Development: The ULI Guide to the Business. Urban Land Institute, Washington DC.

Property Data (2018a) The UK Commercial Developers Directory - 2018 Edition. Property Data Ltd, Eccleshall, UK.

Property Data (2018b) The UK Housebuilders Directory - 2018 Edition. Property Data Ltd, Eccleshall, UK.

Property Data (2019) The UK Housebuilders Directory - 2019 Edition. Property Data Ltd, Eccleshall, UK.

Reed, R. and Sims, S. (2015) Property Development, 6th edition, Routledge, Abingdon, UK.

RICS (2008) Valuation of development land, Valuation Information Paper No. 12, Royal Institution of Chartered Surveyors, London, UK.

Savills (2017) Residential Development Margin: Competitive Return to a Willing Developer, March 2017. Savills: London

Sayce, S., Crosby, N., Garside, P., Harris, R. and Parsa, A. (2017) Viability and the Planning System: The Relationship Between Economic Viability Testing, Land Values and Affordable Housing in London, Kingston University, Ramidus, Royal Agricultural University and the University of Reading.

Southwark London Borough Council (2014) Southwark's Community Infrastructure Levy (CIL): LBS survey of viability appraisals submitted with planning applications, December 2014.

Wellings, F. (2006) British Housebuilders: History \& Analysis, Blackwell, Oxford.

Wiegelmann, T. W. (2012) Risk Management in the Real Estate Development Industry: Investigations into the application of risk management concepts in leading European real estate development organisations. PhD thesis. Bond University, Australia.

Wyatt, P. (2013) Property Valuation, Second edition, Wiley-Blackwell, Chichester. 
Table 1: Benchmarks used for the expected profit/return from a development scheme at the initial feasibility stage

\begin{tabular}{|l|c|c|c|c|c|c|}
\hline & Always & Usually & $\begin{array}{c}\text { Around } \\
\text { half the } \\
\text { time }\end{array}$ & Sometimes & Never & Total \\
\hline Profit on costs & $68(64 \%)$ & $22(21 \%)$ & $1(1 \%)$ & $5(5 \%)$ & $11(10 \%)$ & 107 \\
\hline Profit on value & $43(46 \%)$ & $18(19 \%)$ & 0 & $17(18 \%)$ & $15(16 \%)$ & 93 \\
\hline $\begin{array}{l}\text { Return on capital } \\
\text { employed }\end{array}$ & $36(38 \%)$ & $17(18 \%)$ & $4(4 \%)$ & $26(27 \%)$ & $12(13 \%)$ & 95 \\
\hline Project IRR & $30(32 \%)$ & $14(15 \%)$ & $6(6 \%)$ & $20(21 \%)$ & $25(26 \%)$ & 95 \\
\hline Profit on equity invested & $24(28 \%)$ & $11(13 \%)$ & $3(4 \%)$ & $18(21 \%)$ & $29(34 \%)$ & 85 \\
\hline Equity IRR & $13(17 \%)$ & $12(15 \%)$ & $5(6 \%)$ & $9(12 \%)$ & $39(50 \%)$ & 78 \\
\hline Equity multiple & $8(11 \%)$ & $10(14 \%)$ & $4(5 \%)$ & $10(14 \%)$ & $42(57 \%)$ & 74 \\
\hline Other & $4(16 \%)$ & $2(8 \%)$ & $1(4 \%)$ & $1(4 \%)$ & $17(68 \%)$ & 25 \\
\hline
\end{tabular}

Table 2: Factors that influence the level of developer's required profit/return

\begin{tabular}{|l|c|c|c|}
\hline & Mean & $\begin{array}{c}\text { Standard } \\
\text { deviation }\end{array}$ & $\begin{array}{c}\text { Number } \\
\text { of } \\
\text { responses }\end{array}$ \\
\hline State of market & 70.0 & 22.5 & 114 \\
\hline Planning permission status & 68.0 & 26.6 & 108 \\
\hline Site-specific risk (e.g. brownfield, abnormal costs) & 67.5 & 22.3 & 112 \\
\hline Location (region, in/out of town or urban/rural) & 64.5 & 27.1 & 107 \\
\hline Ratio of costs to value (operating leverage) & 61.8 & 26.4 & 104 \\
\hline $\begin{array}{l}\text { Land use (office, retail, industrial, housing, apartments, } \\
\text { mixed) }\end{array}$ & 56.5 & 29.7 & 108 \\
\hline Nature of end-user (investor/occupier, market/not-for-profit) & 55.7 & 27.3 & 103 \\
\hline Size of scheme & 52.0 & 24.7 & 106 \\
\hline
\end{tabular}


Figure 1 - Median IRR from UK developments, all property types: 1983 to 2014

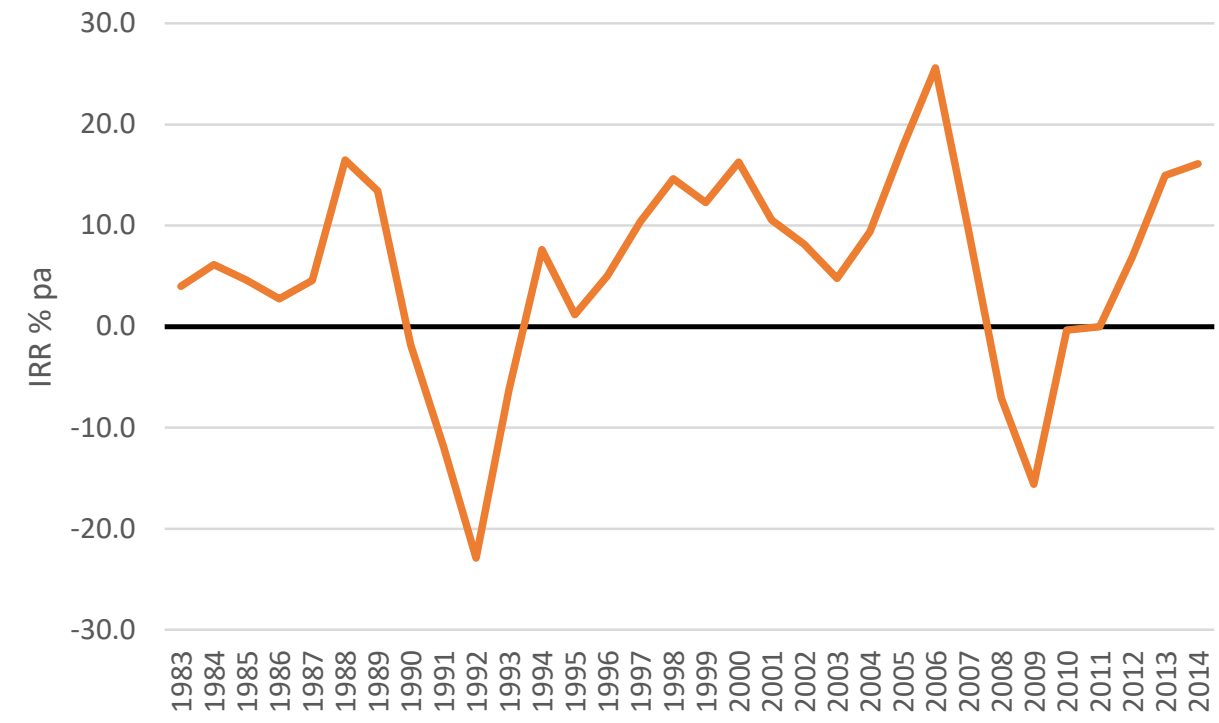

Source: Based on data from IPD (2015). Date reflects year of scheme completion.

Figure 2 - Means and standard deviations for IRR series split by type of activity and type of use

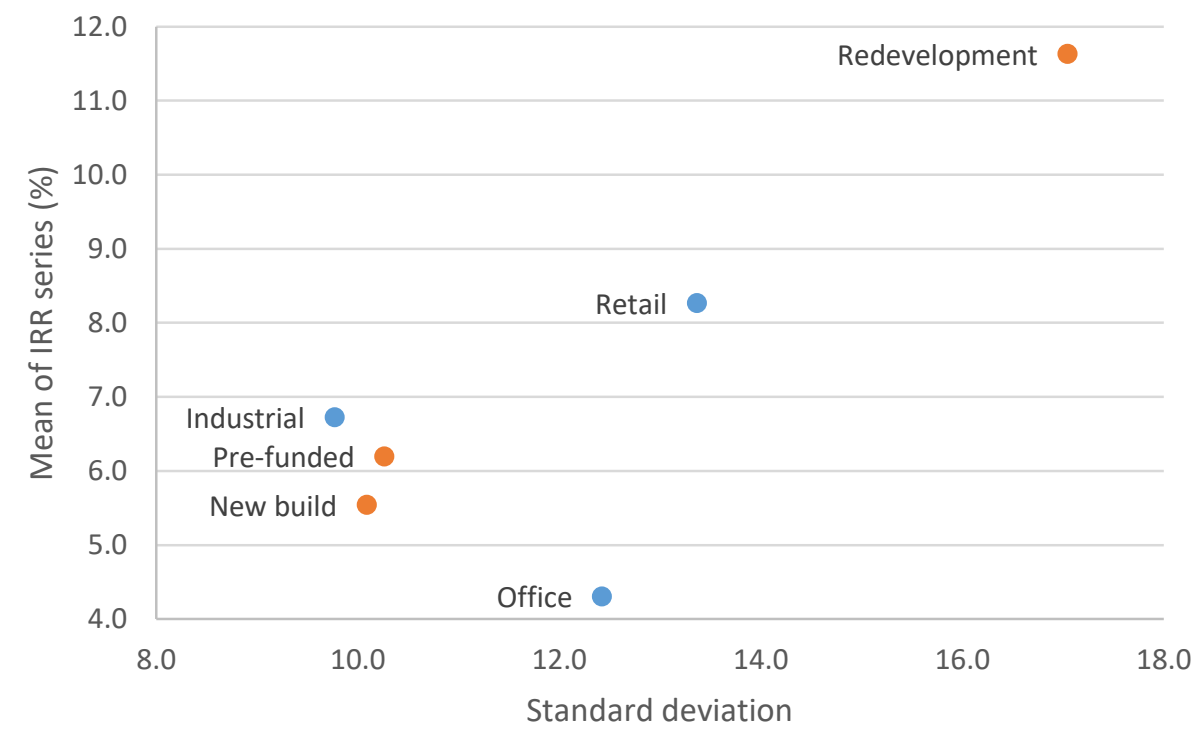

Source: Based on data from IPD (2015). 
Figure 3: Means and standard deviations for IRR series split by scheme length

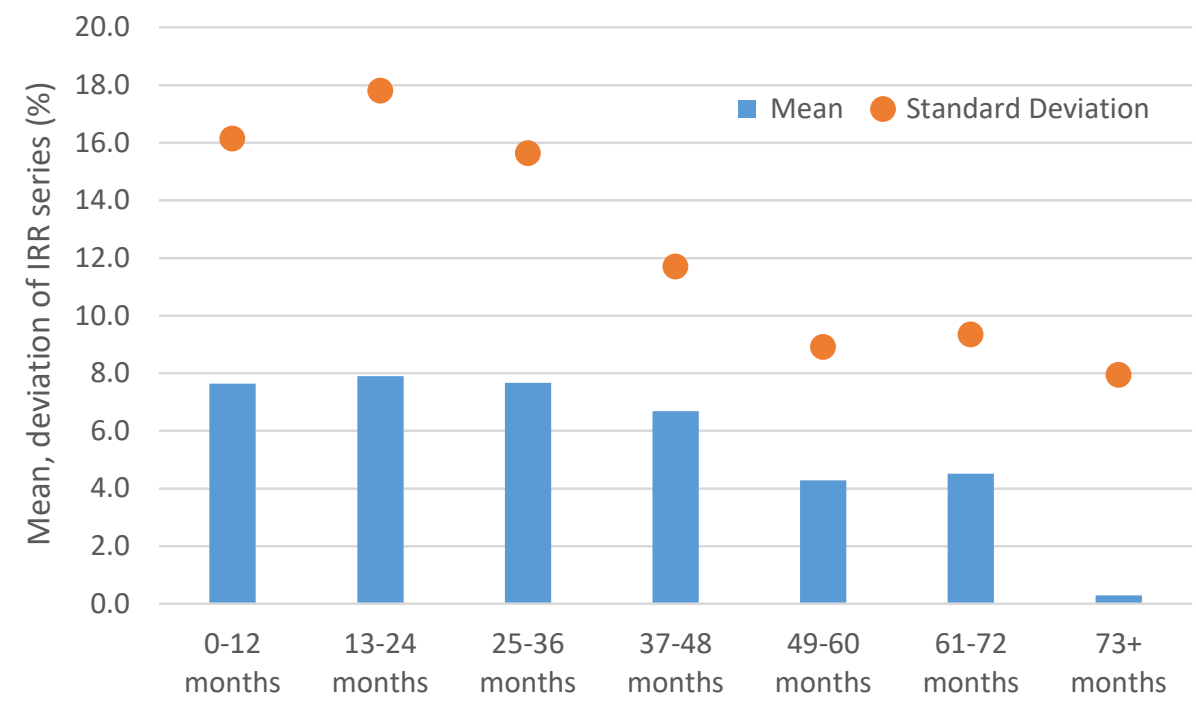

Source: Based on data from IPD (2015).

Figure 4: Average profit margin and return on capital for major UK housebuilders: 1998 to 2017

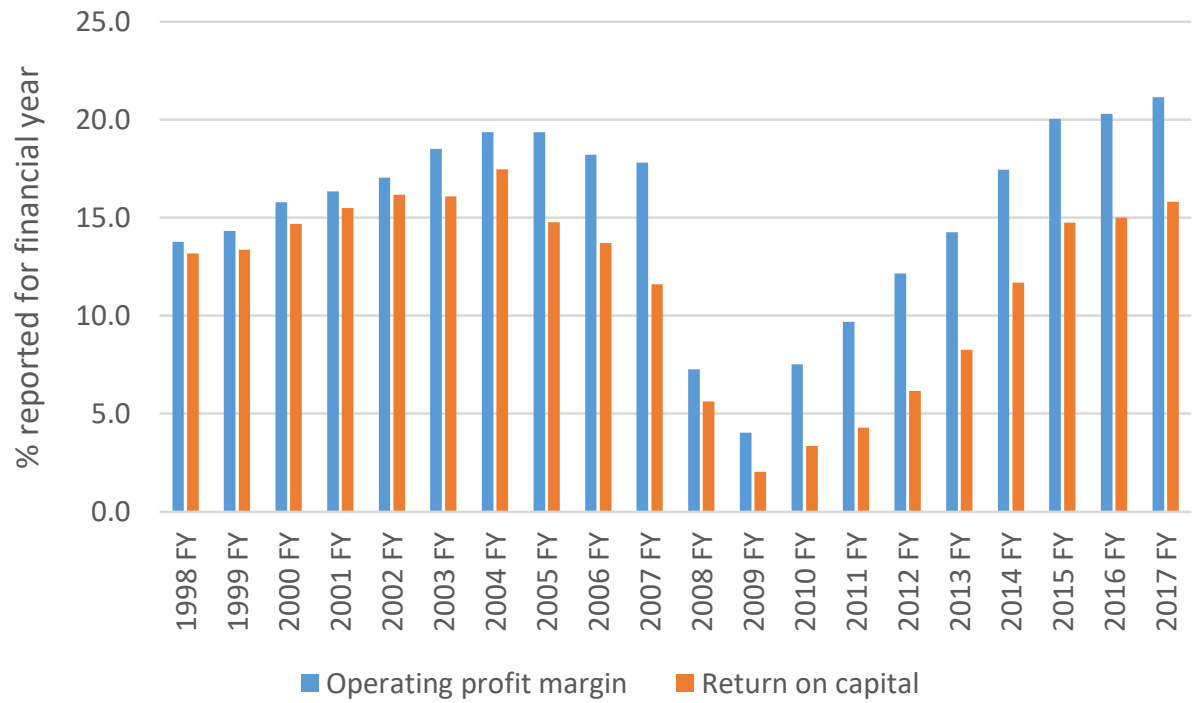

Source: Based on data from S\&P Global Market Intelligence. 
Figure 5: Mean operating profit for the top 200 UK housebuilders, by turnover of firm: 2017-2019

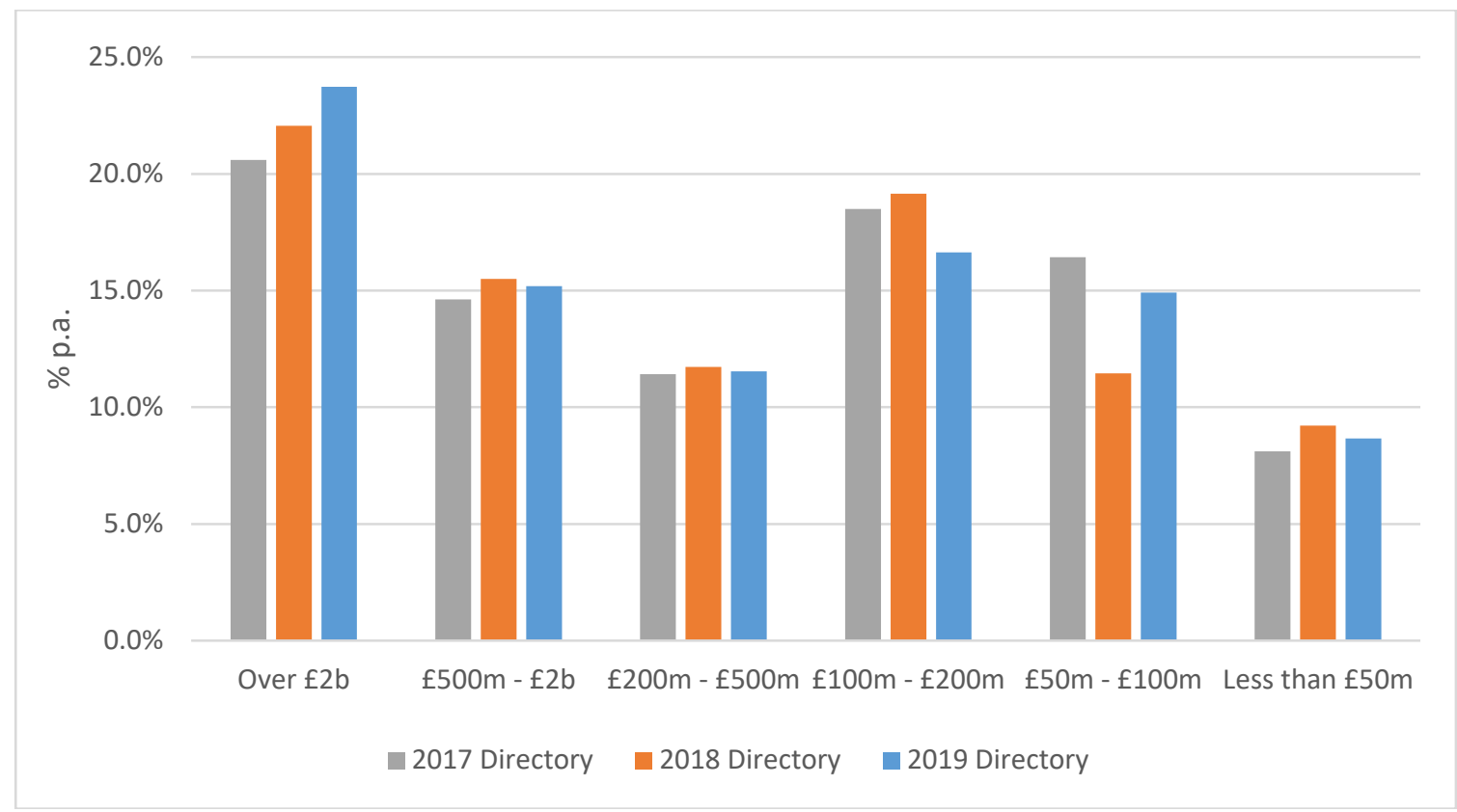

Source: Calculated using data extracted from Property Data (2019) by the authors

Figure 6: Use of conventional residual and cash flow-based appraisal methods by residential and not solely residential developers

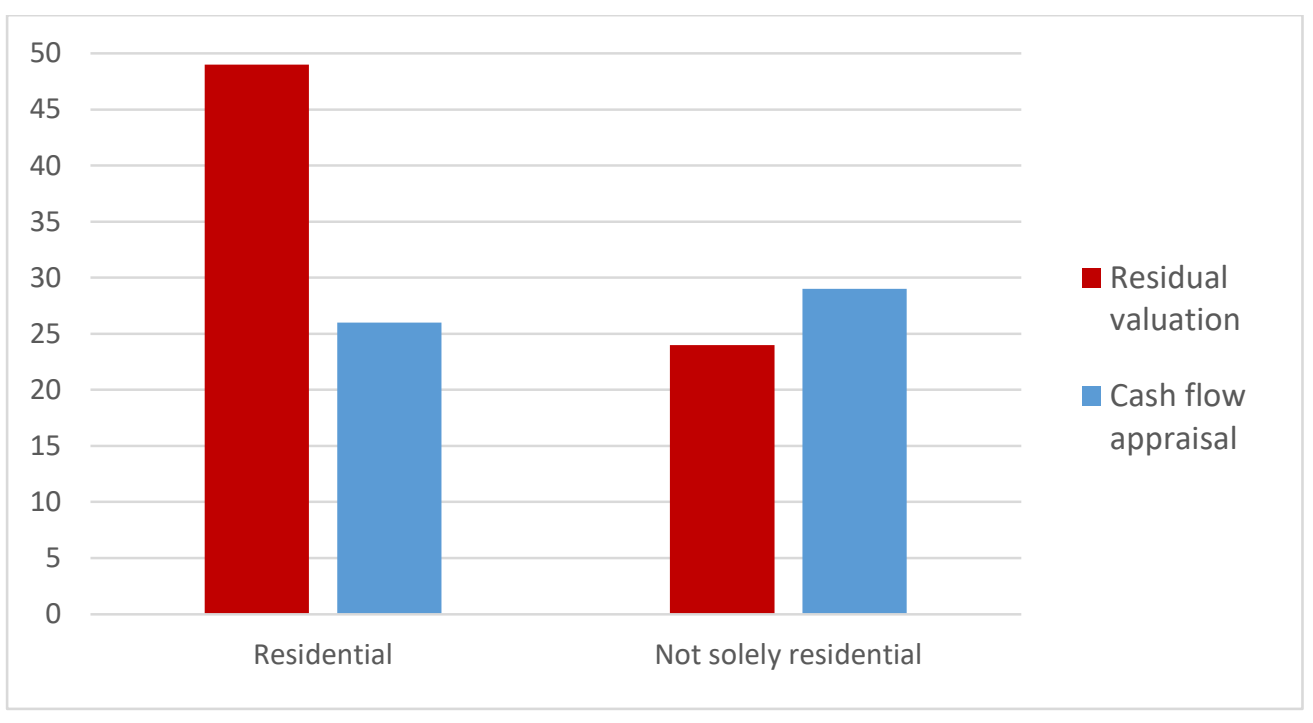


Figure 7: Inclusion of finance costs in appraisals at the initial feasibility stage

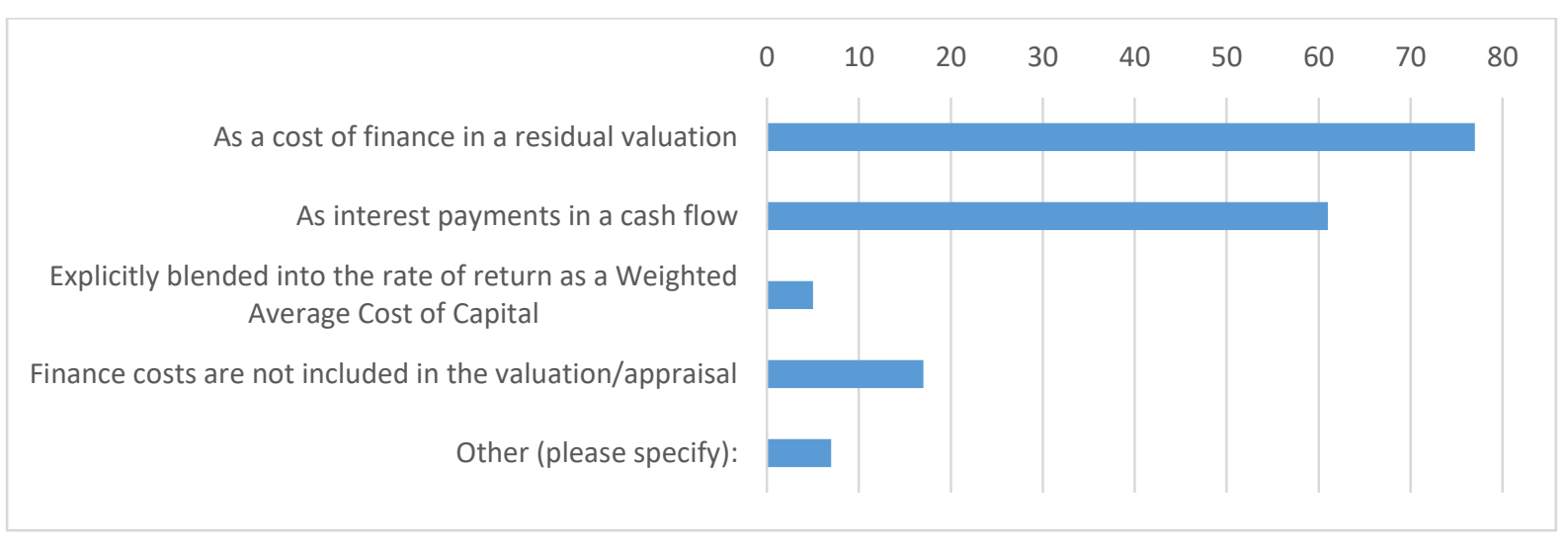

Figure 8: How developer's profit or return target changes depending on the length of the scheme

\begin{tabular}{|r|r|r|r|r|r|}
\hline \\
It would increase for longer developments
\end{tabular}


Figure 9: How developer's profit or return target changes for a mixed-use scheme

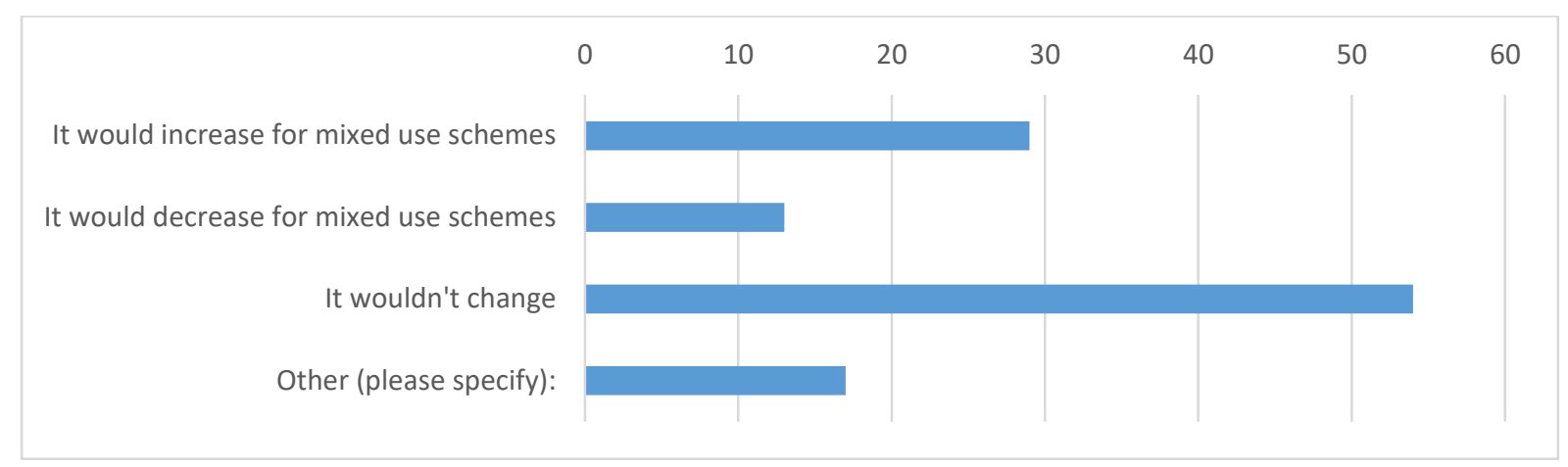

Figure 10: How frequently appraisals are back-tested once projects are completed

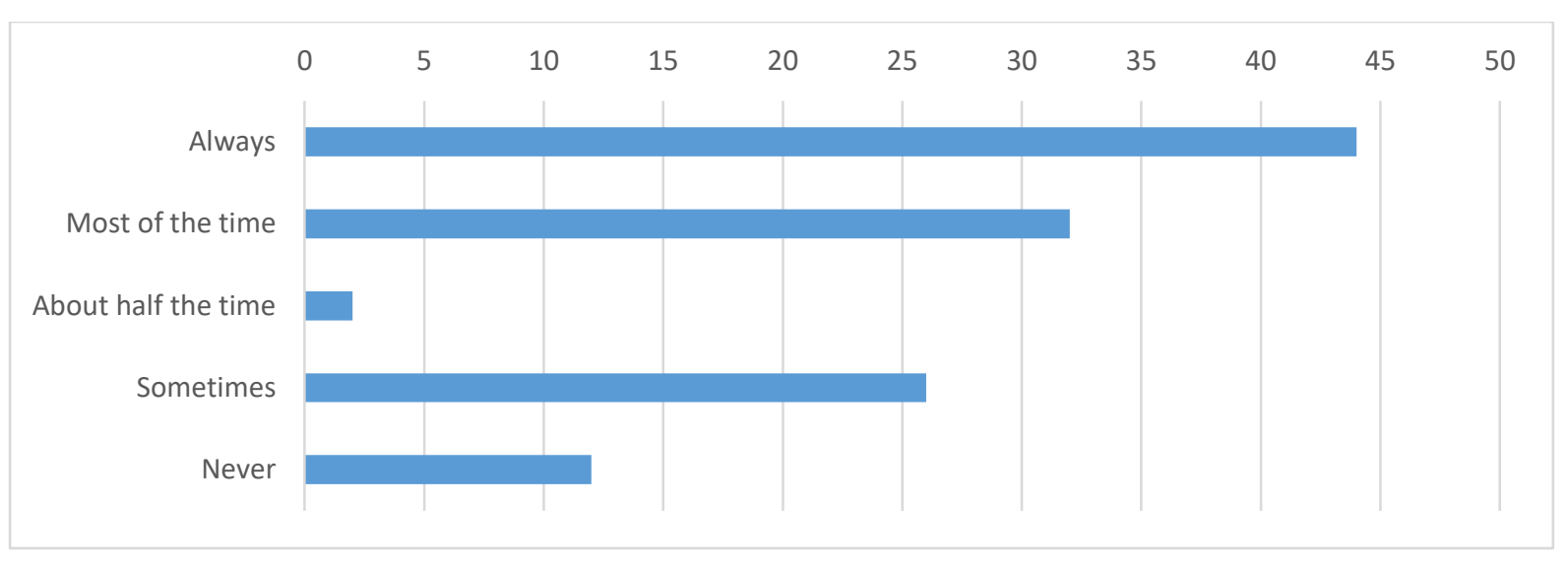

